\title{
Growth and Photosynthetic Pigments of Cotton Cultivars Irrigated with Saline Water
}

\author{
Elka Costa Santos Nascimento, Ronaldo do Nascimento, André Alisson Rodrigues da Silva, \\ Carlos Vailan de Castro Bezerra, Mateus Costa Batista, Luana Lucas de Sá Almeida Veloso, \\ Márcia Cristina de Araújo Pereira, Hallyson Oliveira
}

Federal University of Campina Grande, Campina Grande, Brazil

Email: hallysonoliveira_@hotmail.com, elka_costa@hotmail.com, ronaldon453@gmail.com, anndrealisson_cgPB@hotmail.com, carlosuailan@hotmail.com, matheus1384@hotmail.com, luana_lucas_15@hotmail.com,marcia.cris19@h otm ail.com

How to cite this paper: Nascimento, E.C.S., do Nascimento, R., da Silva, A.A.R., de Castro Bezerra, C.V., Batista, M.C., de Sá Almeida Veloso, L.L., de Araújo Pereira, M.C. and Oliveira, H. (2019) Growth and Photosynthetic Pigments of Cotton Cultivars Irrigated with Saline Water. Agricultural Sciences, 10, 81-91.

https://doi.org/10.4236/as.2019.101007

Received: December 20, 2018

Accepted: January 18, 2019

Published: January 21, 2019

Copyright (c) 2019 by author(s) and Scientific Research Publishing Inc. This work is licensed under the Creative Commons Attribution International License (CC BY 4.0).

http://creativecommons.org/licenses/by/4.0/

\section{cc) (i) Open Access}

\begin{abstract}
The cultivation of cotton is a relevant socioeconomic activity in the Brazilian agricultural scenario. In the Brazilian Northeast, however, production is limited by low rainfall, requiring water supplementation, a problem for the cotton cultivation practiced in the semi-arid region, due to the presence of saline ions in several water sources, from where the water is used for irrigation. It is necessary to identify cultivars that better tolerate saline stress in order to provide subsidies for their cultivation under such conditions. In this sense, the objective was to evaluate the tolerance of cotton cultivars to salinity. The experiment was conducted in a greenhouse, belonging to the Natural Resource Technology Center of the Federal University of Campina Grande, Campus I, Campina Grande, Brazil, in a completely randomized design in a 2 $\times 5$ factorial scheme, with four replications, totaling 40 experimental units (BRS $368 \mathrm{RF}$ and BRS SAFIRA) submitted to five saline levels (1.5, 3.0, 4.5, 6.0 and $\left.7.5 \mathrm{dS} \cdot \mathrm{m}^{-1}\right)$. Irrigation with water saline of EC from $1.5 \mathrm{dS} \cdot \mathrm{m}^{-1}$ affects adversely the growth of cotton cultivars, causing reductions in plant height, stem diameter, leaf area and number of leaves. Saline stress reduced the levels of the photosynthetic pigments of the cotton plants studied.
\end{abstract}

\section{Keywords}

Gossypium hirsutum L., Salinity, Chlorophyll

\section{Introduction}

The cultivation of cotton has been highlighted as an activity of great socioeconomic importance, especially for the Brazilian agribusiness, cultivated in more 
than fifteen states, with emphasis on the herbaceous cotton (Gossypium hirsutum L.). Oliveira et al., (2012) [1] presented an estimate of 3.6 million tons of herbaceous cotton for the 2017 harvest [2].

In the semi-arid region of the Northeast, cotton production is one of the main agricultural activities of small and medium producers [3]. Cotton can be expressed as a farm alternative, due to the lower water requirement when compared to other crops, due to its tolerance to salinity, allowing the use of areas affected by salt and the use of water considerate of lower quality (high salt concentration) [4].

The use of water, which has high concentrations of salts, in irrigation for plant production, is a challenge that has been successfully overcome in several parts of the world, due to the use of tolerant species and the adoption of adequate management practices of crops, soil and irrigation water [5].

The plants, when cultivated under soil with salinity or irrigated with water saline, have their growth compromised due to the osmotic effect, which reduces the water absorption by the plant and/or as a function of the specific effect of the ions that cause functional disorders and damages, especially in leaves, thus affecting plant metabolism [6]. Thus, salinity can be considered as one of the abiotic stresses that most limits plant growth [7].

Biochemical and physiological processes are triggered in plants submitted to saline stress, which consequently interfere with their growth, stomatal behavior and photosynthetic capacity [8], due to the osmotic effects of the salts and the specific characteristics of $\mathrm{Na}^{+}$and $\mathrm{Cl}^{-}$[9].

Qiu et al., (2014) [10] reported that saline stress, specifically, promotes the inhibition of the chlorophyllase enzyme, which results in a reduction in the levels of chlorophyll and its precursor, 5-aminolevulinate.

Processes such as changes in fluorescence, may indicate the absence or presence of damage in the photosynthetic process, since the concentration of photosynthetic pigments, mainly chlorophyll a and chlorophyll $b$, is included in the factors linked to the photosynthetic efficiency of the plants because they are responsible for the capture of the light energy, later converted into chemical energy [11]. The fluorescence of Chlorophyll has become a method widely used for evaluating plant responses to environmental stresses [12].

The objective of this study was to evaluate the growth and content of photosynthetic pigments of two cotton cultivars submitted to saline stress.

\section{Material and Methods}

The experiment was conducted from November 2017 to April 2018, in greenhouse conditions at the Natural Resources Technology Center of the Federal University of Campina Grande (CTRN/UFCG), Campina Grande, PB, in the mesoregion of the Agreste Paraibano, situated by the geographical coordinates $7^{\circ} 15^{\prime} 18^{\prime \prime} \mathrm{S}$ latitude $35^{\circ} 52^{\prime} 28^{\prime \prime} \mathrm{W}$ longitude and average altitude of $550 \mathrm{~m}$; being the climate of the region, according to the climatic classification of Köppen, adapted to Brazil, type Csa, which represents mesothermic climate, sub-humid, with dry 
and hot dry season (4 to 5 months) and rainy season from autumn to winter. At the moment of conduction of the experiment, the effective seasons were spring and summer. These seasons are considering hot with low rainfall, mainly at the semiarid region of the Brazil.

The treatments were distributed in a completely randomized design in a $2 \times 5$ factorial scheme, with four replications, totaling 40 experimental units, corresponding to two cotton cultivars (BRS $368 \mathrm{RF}$ and BRS SAFIRA) associated to five levels of electrical conductivity of irrigation water $(1.5 ; 3.0 ; 4.5 ; 6.0$ and 7.5 $\left.\mathrm{dS} \cdot \mathrm{m}^{-1}\right)$.

Salinized water was prepared by the addition of different amounts of sodium chloride $(\mathrm{NaCl})$ in the local water supply $\left(\mathrm{EC}=0.8 \mathrm{dS} \cdot \mathrm{m}^{-1}\right)$, the amount being determined taking into account the relationship between ECw and concentration of salts $\left(10^{*} \mathrm{mmolc} \cdot \mathrm{L}^{-1}=1 \mathrm{dS} \cdot \mathrm{m}^{1}\right)$.

The plants were cultivated in plastic pots, with 20 liters of capacity. At the base of the vessel was connected a transparent hose of $10 \mathrm{~mm}$ diameter, for collection of the drained volume, in PET bottles of $2.0 \mathrm{~L}$ volumetric capacity. The end of the hose that is inside the vessel for collection of the drainage water was wrapped with a nonwoven geotextile blanket (Bidim OP 30) to prevent its obstruction by the soil material. The pots were filled with a $3 \mathrm{~cm}$ layer of gravel at the base and $18 \mathrm{~kg}$ of soil classified as Eutrophic Greyish Argissolo with a sandy-loam texture collected at depth of $0-20 \mathrm{~cm}$ from the rural area of the municipality of Lagoa Seca, being properly disintegrated and sieved, whose physical-hydro and chemical characteristics (Table 1) were determined according to the methodologies proposed by [13]. In additional, the spacing of the plants was $0.5 \mathrm{~m}$ between plants in row and $0.5 \mathrm{~m}$ between vessels.

After filling the pots, soil moisture content was elevated close to the field capacity and maintained throughout the research, with daily irrigations applied in each vessel related to the water corresponding to the treatments. The volume applied was estimated by the water balance: volume of water applied minus the

Table 1. Chemical and physical-water attributes of the soil used in the experiment, before to the application of the treatments.

\begin{tabular}{|c|c|c|c|c|c|c|c|c|c|}
\hline \multicolumn{9}{|c|}{ Chemical Characteristics } & \multirow[b]{2}{*}{$\begin{array}{l}\text { ECes } \\
\left(\mathrm{dS} \cdot \mathrm{m}^{-1}\right)\end{array}$} \\
\hline $\begin{array}{c}\mathrm{pH}\left(\mathrm{H}_{2} \mathrm{O}\right) \\
(1: 2.5)\end{array}$ & $\begin{array}{c}\text { M.O. } \\
\%\end{array}$ & $\begin{array}{c}\mathrm{P} \\
\left(\mathrm{meq} \cdot \mathrm{kg}^{-1}\right)\end{array}$ & \multicolumn{4}{|c|}{$\left(\right.$ meqkg $\left.{ }^{-1}\right)$} & $\mathrm{Al}^{3+}+\mathrm{H}^{+}$ & $\begin{array}{l}\text { PST } \\
(\%)\end{array}$ & \\
\hline 5.90 & 1.36 & 6.80 & 2.22 & 1.60 & 26.00 & 36.60 & 19.30 & 1.87 & 1.0 \\
\hline \multicolumn{10}{|c|}{ Physical-Hydro Characteristics } \\
\hline \multicolumn{3}{|c|}{$\begin{array}{l}\text { Granulometric Fraction } \\
\qquad\left(\text { dag kg }^{-1}\right)\end{array}$} & \multirow{2}{*}{$\begin{array}{c}\text { Textural } \\
\text { Class }\end{array}$} & \multicolumn{2}{|c|}{ Moisture (kPa) } & \multirow{2}{*}{$\mathrm{AD}$} & \multirow{2}{*}{$\begin{array}{c}\text { Total } \\
\text { Porosity } \\
\%\end{array}$} & $\mathrm{DA}$ & \multirow[b]{2}{*}{$\left.\mathrm{cm}^{-3}\right)$} \\
\hline Sand & Silte & Clay & & 33.42 & $\begin{array}{c}1519.5 \\
\text { dag. } \mathrm{kg}^{-1}\end{array}$ & & & & \\
\hline 732.9 & 142.1 & 125.0 & FA & 11.98 & 4.32 & 7.66 & 47.74 & 1.39 & 2.66 \\
\hline
\end{tabular}

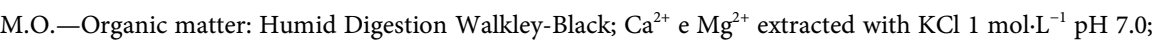
$\mathrm{Na}^{+}$e $\mathrm{K}^{+}$extracted using $\mathrm{NH}_{4} \mathrm{OAc} 1 \mathrm{~mol} \cdot \mathrm{L}^{-1} \mathrm{pH}$ 7.0; PST-Percentage of Exchangeable Sodium; ECes-Eletric Conductivity of saturation extract; FA-Sandy Franc; AD—Water Available; DA-Apparently Density; DP-Density of Particles. 
volume of water drained in the previous irrigation, plus leaching fraction of 0.15 , in order to avoid excessive accumulation of salts in the soil [14].

Sowing was performed with 4 seeds, which from the sowing, were submitted to the treatments. They were distributed equidistantly directly in the vessel, at a depth of $1.5 \mathrm{~cm}$. At 20 days after sowing, the thinning was done leaving only the most vigorous seedling until the end of the experiment.

Fertilization with nitrogen $(\mathrm{N})$, phosphorus $(\mathrm{P})$ and potassium $(\mathrm{K})$ was performed according to the recommendations of [15], with 100,150 and $300 \mathrm{mg} \cdot \mathrm{kg}^{-1}$ of $\mathrm{N}, \mathrm{K}_{2} \mathrm{O}$ and $\mathrm{P}_{2} \mathrm{O}_{5}$, respectively, being applied together with the irrigation water, with the potassic and phosphate fertilizations being divided into two equal applications, at intervals of 45 days, with the first application one day before sowing (DAS) and the nitrogen application divided into three applications, the first one being at 30 days after sowing, in a 30 day interval. The sources of nitrogen, phosphorus and potassium were urea, monoammonium phosphate and potassium chloride, respectively.

For the phytosanitary control were sprayed using vegetable oil of Nim and Mospilan aiming the control of white fly according to the recommendation of the manufacturers. Spraying was performed at $5 \mathrm{pm}$.

The growth variables were evaluated at 80 and 100 DAS, being plant height (AP), stem diameter (DC), number of leaves (NF), leaf area (FA) of cotton cultivars, and physiological parameters as chlorophyll content was performed at 20 DAS.

The plant height was obtained taking as reference the distance from the lap of the plant until the insertion of the apical meristem. The stem diameter was measured at $3 \mathrm{~cm}$ from the plant neck, with the aid of a digital caliper. The number of leaves was obtained by counting fully expanded leaves with a minimum length of $3 \mathrm{~cm}$. The leaf area was obtained by measuring the length of the main vein of all leaves of the plant, according to equation [16], Equation (1).

$$
A F=\sum\left(0.4322 \times P^{2.3002}\right)
$$

The chlorophyll contents were carried out in the laboratory of plant physiology of the Federal University of Campina Grande. For the procedure, a leaf disc with a diameter of $0.771 \mathrm{~mm}$ of the leaf blade was removed by means of a punch, between the edge and the central vein of the leaf. The sample weight should vary between $50-200 \mathrm{~g}$. The chlorophyll content a and b, total and the carotenoids were quantified by extracting the pigments from fresh leaf samples, which after being weighed, were punched and placed in recipients containing $6 \mathrm{~mL}$ of $80 \%$ acetone, which were kept in the dark and in a refrigerator for 48 hours; the supernatants containing the extracted pigments were collected and the spectrophotometer absorbance readings were taken at 470, 645 and 663 nanometers, according to [17] and [18]. The absorbance values are converted to the contents of chlorophyll a, b, total and carotenoids through Equations (2), (3), (4) and (5) respectively, originally proposed by [17] and still used by others authors [19]: 


$$
\begin{gathered}
\text { Chlorophylla }=(12.25 \times A 663-2.79 \times A 647) \\
\text { Chlorophyllb }=(21.5 \times A 647-5.10 \times A 663) \\
\text { Total chlorophyll }=(7.15 \times A 663)+(18.71 \times A 647) \\
\text { Total carotenoids }=(1000 \times A 470-1.82 C l a-85.02 C l b) / 198
\end{gathered}
$$

The values obtained were converted to $\mu$ g of pigment per gram of fresh mass, by a simple three rule.

The data obtained were evaluated by analysis of variance by the " $\mathrm{F}$ " test at the 0.05 and 0.01 probability level and in the cases of significance, linear and quadratic polynomial regression analysis was performed for the "salinity" factor, and in the "cultivar" factor, the Tukey test was used to compare means at 5\% probability using the statistical software SISVAR 5.6 [20].

\section{Results and Discussion}

Based on the results of the analysis of variance of the data (Table 2), it was verified that there was a significant effect of the salinity levels of the irrigation water of the cotton on the biometric variables: plant height (AP), stem diameter (DC) leaf area (FA) and number of leaves (NF), in all periods studied. The cultivar factor was significant only for the number of leaves at 80 and 100 days after sowing.

It is observed in Figure 1(a) that the increase of the salinity in the irrigation water affected negatively the height of the cotton plants in all evaluated epochs and, according to regression equations (Figure 1(a)), it is verified reductions of $5.53 \%$ to $80 \%$ DAS and $5.87 \%$ to $100 \%$ DAS per unit increase in electrical conductivity, and thus represent decreases of 27.84 and $31.59 \mathrm{~cm}$ in the height of the plants irrigated with $7.5 \mathrm{dS} \cdot \mathrm{m}^{-1}$ in relation to those submitted to irrigation with water of $1.5 \mathrm{dS} \cdot \mathrm{m}^{-1}$, at 80 and 100 DAS respectively. The reduction in the absolute value for this variable must be associated to the excess of salts in the soil, causing, according to [21], a change in the external water potential and the ionic effect, caused by the accumulation of ions in the vegetal tissues, damage to various physiological and biochemical processes such as photosynthesis, protein synthesis and lipid metabolism, and may cause serious damage to growth.

A linear and decreasing response is observed through the regression equation with the increase of the electrical conductivity of the irrigation water. According to the regression equation for the stem diameter of the cotton plant (Figure 1 (b)), it can be observed that the plants showed reductions of 31.85 and $28.85 \%$, respectively, at 80 and $100 \mathrm{DAS}$, in the plants submitted to the highest ECw in comparison with the lowest level of water salinity $\left(1.5 \mathrm{dS} \cdot \mathrm{m}^{-1}\right)$. Therefore, due to the reductions in stem diameter, as well as in height, they show a reflection of excess salts in the root zone, causing a deleterious effect on the growth of the plants, which showed a marked decrease in the growth of different organs, because the excess of salts restricts the turgor of expanding tissues [22]. Following the same trend as plant height and stem diameter (Figure 1(a) and Figure 1(b)), 
Table 2. Summary of the "F" test for plant height (AP), stem diameter (DC), leaf area (FA) and number of leaves (NF) of cotton cultivars irrigated with saline water at 80 and 100 DAS.

\begin{tabular}{|c|c|c|c|c|c|c|c|c|c|}
\hline \multicolumn{10}{|c|}{ MIDDLE SQUARE } \\
\hline Tratamentos & GL & \multicolumn{2}{|c|}{ AP } & \multicolumn{2}{|c|}{ DC } & \multicolumn{2}{|c|}{$\mathrm{AF}$} & \multicolumn{2}{|c|}{$\mathrm{NF}$} \\
\hline & & 80 & 100 & 80 & 100 & 80 & 100 & 80 & 100 \\
\hline Salinity $\left(\mathrm{dS} \mathrm{m} \mathrm{m}^{-1}\right)$ & 4 & $1006.86^{\star *}$ & $1308.10^{\star *}$ & $12.11^{\star *}$ & $9.09^{* *}$ & $3223610.56^{\star *}$ & $4897387.66^{* *}$ & $333.04^{\star *}$ & $833.96^{\star *}$ \\
\hline Linear Regression & 1 & $3878.11^{\star *}$ & $4992.80^{\star *}$ & $43.41^{\star *}$ & $35.55^{\star \star}$ & $12336612.20^{\star *}$ & $19261819.18^{\star *}$ & $918.01^{\star *}$ & $3175.20^{\star *}$ \\
\hline Quadratic Regression & 1 & $84.01^{\mathrm{ns}}$ & $75.57^{\mathrm{ns}}$ & $1.47^{\mathrm{ns}}$ & $0.15^{\text {ns }}$ & $87412.76^{\mathrm{ns}}$ & $190838.14^{\mathrm{ns}}$ & $225.72^{\mathrm{ns}}$ & $0.89^{\text {ns }}$ \\
\hline Cultivar & 1 & $237.65^{\mathrm{ns}}$ & $250.00^{\mathrm{ns}}$ & $0.21^{\mathrm{ns}}$ & $0.23^{\text {ns }}$ & $93275.79^{\text {ns }}$ & $729031.35^{\mathrm{ns}}$ & $384.40^{*}$ & $1690.00^{* *}$ \\
\hline Int. (Sal x Cult.) & 4 & $36.31^{\mathrm{ns}}$ & $14.00^{\mathrm{ns}}$ & $0.47^{\mathrm{ns}}$ & $0.71^{\mathrm{ns}}$ & $137510.01^{\mathrm{ns}}$ & $114592.41^{\mathrm{ns}}$ & $2.59^{\text {ns }}$ & $24.81^{\mathrm{ns}}$ \\
\hline $\mathrm{CV}(\%)$ & & 15.44 & 12.51 & 11.92 & 10.77 & 19.85 & 21.15 & 24.35 & 26.82 \\
\hline
\end{tabular}

${ }^{* * * *}$, ns Significative to $5 \%, 1 \%$ e not significative, respectively.

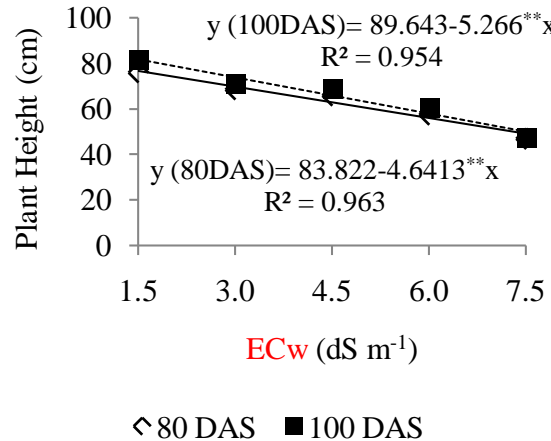

(a)

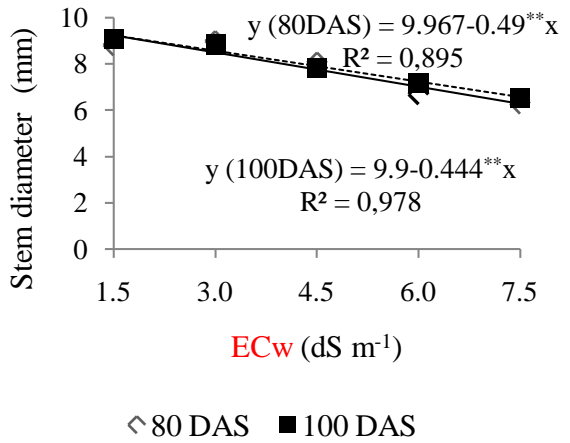

(b)

Figures 1. (a) and (b) Plant height-AP (a) and stem diameter-DC (b), of cotton as a function of salinity of irrigation water, at 80 and 100 DAS.

the leaf area and number of leaves were negatively influenced by the increase of ECw (Figure 2), in the evaluations performed at 80 and 100 DAS.

When analyzing the regression equations for leaf area (AF) and number of leaves of cotton (Figure 2(a) and Figure 2(b)), as a function of water salinity, we can see that the regression model, to which the data fit better, was linear, with percentage reductions in AP of $8.95 \%$ and $9.45 \%$, respectively, per unit increase of ECW, corresponding to a decrease of $1570.8 \mathrm{~cm}^{2}(53.72 \%)$ at 80 DAS and $1962.7 \mathrm{~cm}^{2}(56.69 \%)$ at $100 \%$ of the plants irrigated with water of $7.5 \mathrm{dS} \cdot \mathrm{m}^{-1}$ in comparison with the plants submitted to irrigation with ECw waters equal to 1.5 $\mathrm{dS} \cdot \mathrm{m}^{-1}$. The reduction of leaf area is commonly considered a strategy of protection and/or acclimatization of plants to high salinity, mitigating water losses through the transpiration process and maintaining high water potential in the cell [23].

When analyzing the number of cotton leaves at 80 and $100 \mathrm{DAS}$, it is observed (Figure 2(b)) percentage reductions of $5.31 \%$ and $6.97 \%$, respectively, per unit 


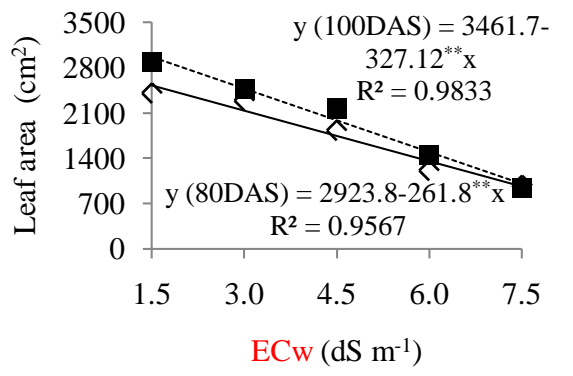

^80 DAS
100 DAS

(a)

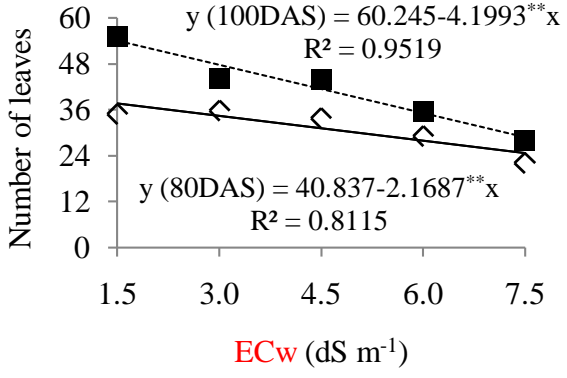

^80 DAS

(b)

Figure 2. (a) and (b) Leaf area-AF (a) and Number of leaves-NF (b), at 80 and 100 DAS of the cotton, as a function of the salinity of the irrigation water.

increase of ECw in the irrigation water, which corresponds to a reduction of approximately 13 and 25 leaves, respectively, in the irrigated plants with higher saline level in relation to those irrigated with the lowest level.

These results corroborate with those found by [24] who also verified reduction in the leaf area of the cotton with the increase of the salinity of the water. [25] also observed a reduction of leaf area and number of leaves when submitted to "BRS Rubi" cotton plants to saline stress, evidencing that the leaves are sensitive organs and as a defense mechanism they reduce in size and number in the presence of high concentrations of salts, in order to reduce water loss through transpiration.

The variable number of leaves differed significantly among cotton cultivars. According to the means test, the cultivar "BRS 368 RF" obtained higher values of number of leaves, being approximately 34 and 48 leaves at 80 and 100 DAS, respectively, with a difference of 7 leaves at 80 DAS and 13 leaves to 100 DAS, in relation to cultivar "BRS Safira" (Figure 3 ).

The ANOVA results for the photosynthetic pigments presented in Table 3 indicated that the levels of chlorophyll $a, b$, total and carotenoids were significantly influenced by the salinity of irrigation water. Already the cultivar factor had a significant effect only on chlorophyll a and carotenoids ( $\mathrm{p}<0.01)$.

The levels of chlorophyll $a, b$, total (CLT) and carotenoids (CAT) differed statistically at 20 DAS with increasing salinity, according to the regression equation (Figure 4) as a function of the salinity of irrigation water, was linear. Chlorophyll a and b (Figure 4(a) and Figure 4(b)) showed reductions of $262.2 \mu \mathrm{g} \cdot \mathrm{g}^{-1}$ MF (38.5\%) and $99.6 \mu \mathrm{g} \cdot \mathrm{g}^{-1} \mathrm{MF}$ (46.1\%), respectively, in plants irrigated with 7.5 $\mathrm{dS} \cdot \mathrm{m}^{-1}$ in relation to those submitted to water irrigation of $1.5 \mathrm{dS} \cdot \mathrm{m}^{-1}$. According to [26], the increase of salt concentrations, and consequent increase in the electrical conductivity of the irrigation water, give rise to stress to the plants by the phytotoxic effect, reflected in the concentration of the photosynthetic pigments.

It was also observed a reduction of approximately $6 \%$ in the total chlorophyll content of the cotton plants per unit increment of ECw (Figure 4(c)). Similar to the total chlorophyll content, carotenoids (Figure 4(d)) had a negative behavior 


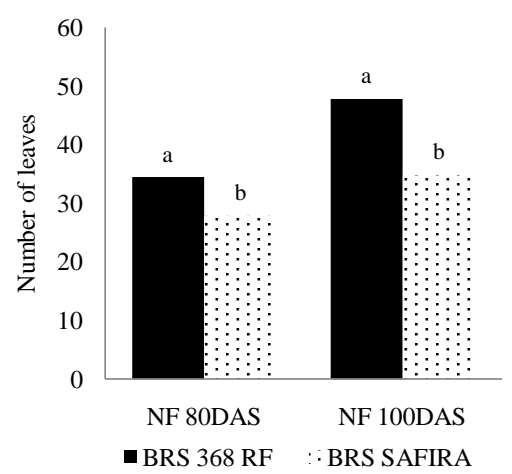

Figure 3. Tukey test for plant height at 80 and 100 DAS of cotton as a function of cultivars "BRS 368 RF" and "BRS Safira".

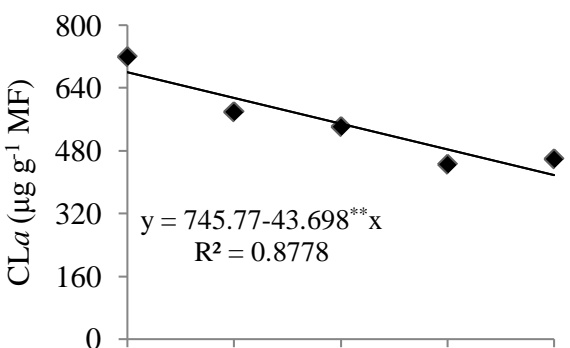

(a)

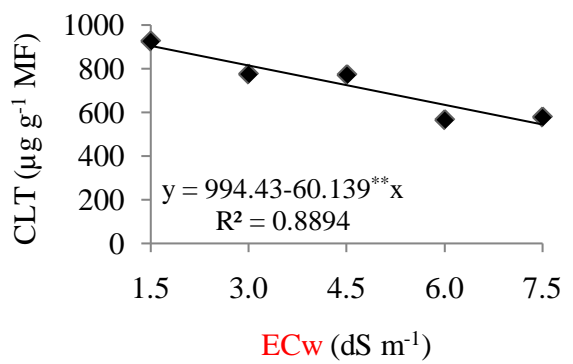

(c)

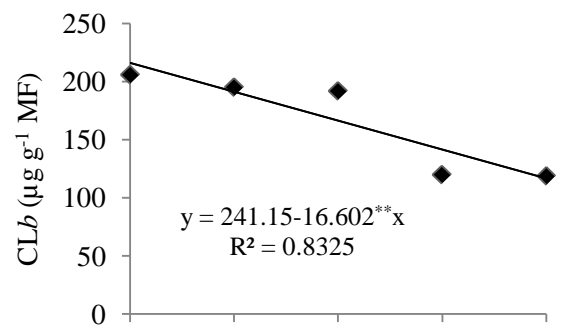

(b)

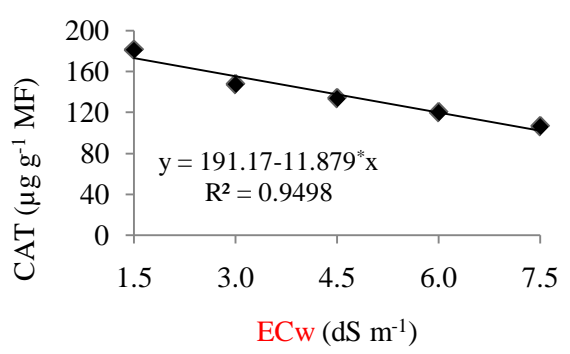

(d)

Figures 4. (a), (b), (c) and (d) Chlorophyll a-CLa (a), chlorophyll b-CLb (b), total chlorophyll-CLT (c) and carotenoid-CAT (d), at 20 DAS of the cotton in function of irrigation water salinity.

with increasing electrical conductivity of the irrigation water, with a decrease of $71.27 \mu \mathrm{g} \cdot \mathrm{g}^{-1} \mathrm{MF}$ between the levels of 1.5 and $7.5 \mathrm{dS} \cdot \mathrm{m}^{-1}$ corresponding to a relative loss of $41.12 \%$, that is, the unit increment of $\mathrm{dS} \cdot \mathrm{m}^{-1}$ in ECw provided a decrease of $6.21 \%$ in the total amount of carotenoids present in cotton leaves, in all periods of study.

According to [27], the reduction in chlorophyll levels is probably due to the imbalance of physiological and biochemical activities due to the excess of salts, besides the tolerance of the cultures. These authors also mention that excess salts can stimulate the enzymatic activity of chlorophyllase that degrades the molecules of the photosynthetic pigment inducing the structural destruction of chloroplasts. 
Table 3. Summary of the analysis of variance for chlorophyll a (CL a), chlorophyll b (CL b) total chlorophyll (CLT) and carotenoid (CAT) of cultivars of cotton irrigated with salt water, 20 DAS.

\begin{tabular}{cccccc}
\hline \multicolumn{5}{c}{ MIDDLE SQUARE } \\
\hline Treatments & GL & CL a & ${ }^{1}$ CL b & CLT & CAT \\
\hline Salinity $\left(\mathrm{dS} \cdot \mathrm{m}^{-1}\right)$ & 4 & $97894.41^{* *}$ & $24.04^{*}$ & $182994.05^{* *}$ & $6776.29^{*}$ \\
Linear Regression & 1 & $343716.40^{* *}$ & $70.55^{* *}$ & $650993.25^{* *}$ & $15068.68^{*}$ \\
Quadratic Regression & 1 & $35830.77^{\mathrm{ns}}$ & $5.83^{\mathrm{ns}}$ & $8576.58^{\mathrm{ns}}$ & $11228.22^{*}$ \\
Cultivar & 1 & $121349.09^{* *}$ & $5.32^{\mathrm{ns}}$ & $142536.14^{\mathrm{ns}}$ & $21533.31^{* *}$ \\
Int. (Sal $\times$ Cult.) & 4 & $49626.68^{\mathrm{ns}}$ & $13.53^{\mathrm{ns}}$ & $101412.60^{\mathrm{ns}}$ & $3644.57^{\mathrm{ns}}$ \\
Residue & 27 & 15024.83 & 8.77 & 37551.64 & 2362.57 \\
CV (\%) & & 22.32 & 23.12 & 26.77 & 36.38 \\
\hline
\end{tabular}

${ }_{* * * *, n s}^{*}$ Significative to $5 \%, 1 \%$ and not significative, respectively. 1statistical analysis performed after data transformation in $\sqrt{x}$.

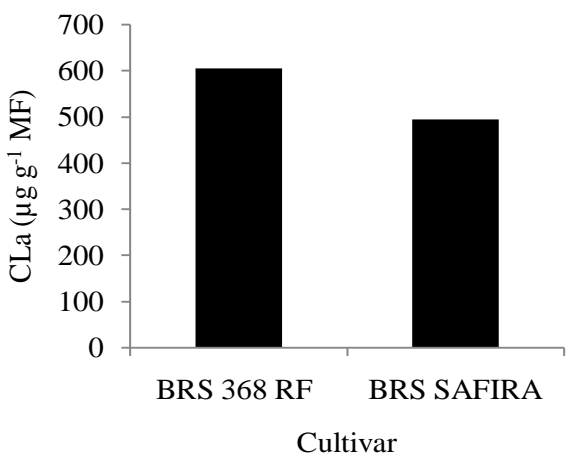

(a)

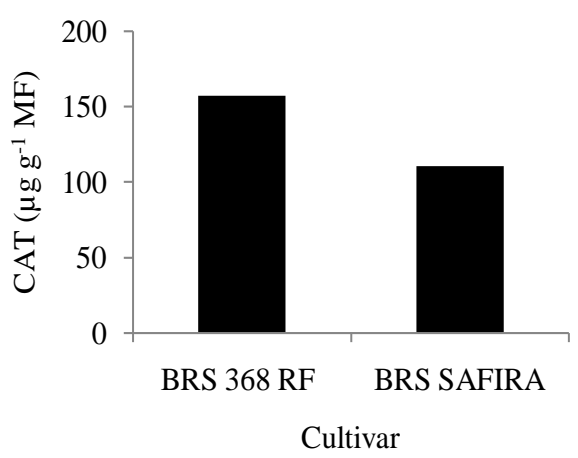

(b)

Figures 5. (a) and (b): Tukey test for chlorophyll a-CLa (a) and carotenoid-CAT (b), at 20 DAS of the cotton as a function of cultivars "BRS 368 RF" and "BRS SAFIRA".

Figure 5 shows the Tukey test among cotton cultivars as a function of irrigation water salinity at 20 DAS. It can be observed that cultivar "BRS 368 RF" showed higher averages for chlorophyll content a and carotenoids, $624.1 \mu \mathrm{g} \cdot \mathrm{g}^{-1}$ $\mathrm{MF}$ and $156.82 \mu \mathrm{g} \cdot \mathrm{g}^{-1} \mathrm{MF}$, respectively, when compared to the cultivar SAFIRA.

\section{Conclusions}

Irrigation with saline water of $1.5 \mathrm{dS} \cdot \mathrm{m}^{-1}$ affects adversely the growth of cotton cultivars, causing reductions in plant height, stem diameter, leaf area and number of leaves.

Saline stress reduces the levels of the photosynthetic pigments of the cotton plants studied.

There was not interaction between salinity factors of irrigation water and cotton cultivars for any of the variables analyzed.

\section{Conflicts of Interest}

The authors declare no conflicts of interest regarding the publication of this paper. 


\section{References}

[1] Oliveira, F.A., Medeiros, J.F., Oliveira, F.R.A., Freire, A.G. and Soares, L.C.S. (2012) Produção do algodoeiro em função da salinidade e tratamento de sementes com regulador de crescimento. Revista Ciência Agronômica, 43, 279-287. https://doi.org/10.1590/S1806-66902012000200010

[2] IBGE (2017) Instituto Brasileiro de Geografia e Estatística. http://agenciadenoticias,ibge.gov.br/2013-agencia-de-noticias/releases/9736-em-dez embro-ibge-preve-safra-16-1-maior-para-2017 qr

[3] Cavalcante, A.C.P., Diniz, B.L.M.T., Silva, A.G., Diniz Neto, M.A., Oliveira, D.S. and Cavalcante, A.P. (2015) Crescimento, produção e características tecnológicas da fibra de algodão colorido em diferentes coberturas no solo. Agropecuária Técnica, 36, 240-247.

[4] Jácome, A.G., Oliveira, R.H., Fernandes, P.D. and Gonçalves, A.C.A. (2003) Comportamento produtivo de genótipos de algodão sob condições salinas. Acta Scientiarum Agronomy, 25, 187-194. https://doi.org/10.4025/actasciagron.v25i1.2669

[5] Rhoades, J., Kandiah, A. and Mashali, A.M. (2000) Uso de águas salinas para produção agrícola. UFPB, Campina Grande, 117.

[6] Nobre, R.G., Lima, G.S., Gheyi, H.R., Lourenço, G.S. and Soares, L.A.A. (2013) Emergência, Crescimento e produção da mamoneira sob estresse salino e adubação nitrogenada. Revista Ciência Agronômica, 44, 76-85. https://doi.org/10.1590/S1806-66902013000100010

[7] Pedrotti, A., Chagas, R.M., Ramos, V.C., Prata, A.P.M., Lucas, A.A.T. and Santos, P.B. (2015) Causas e consequências do processo de salinização dos solos. Revista Eletrônica em Gestão, Educação e Tecnologia Ambiental, 19, 1308-1324.

[8] Nunkaewa, T., Kantachote, D., Kanzaki, H., Nitoda, T. and Ritchie, R.J. (2014) Effects of 5-Aminolevulinic Acid (ALA)-Containing Supernatants from Selected Rhodopseudomonas palustris on Rice Growth under $\mathrm{NaCl}$ Stress, with Mediating Effects on Chlorophyll, Photosynthetic Electron Transport and Antioxidative Enzymes. Electronic Journal of Biotechnology, 17, 19-26.

https://doi.org/10.1016/j.ejbt.2013.12.004

[9] Graciano, E.S.A., Rejane, J.M.C., Nogueira, R.J.M.C., Lima, D.R.M., Pacheco, C.M. and Santos, S.R.C. (2011) Crescimento e capacidade fotossintética da cultivar de amendoim BR 1 sob condições de salinidade. Revista Brasileira de Engenharia Agrícola e Ambiental, 15, 794-800. https://doi.org/10.1590/S1415-43662011000800005

[10] Qiu, Z.B., Guo, J., Jhu, A.J., Zhang, L. and Zhang, M.M. (2014) Exogenous Jasmonic Acid Can Enhance Tolerance of Wheat Seedlings to Salt Stress. Ecotoxicology and vironmental Safety, 104, 202-208. https://doi.org/10.1016/j.ecoenv.2014.03.014

[11] Strasser, R.J., Srivastava, A. and Tsimilli-Michael, M. (2000) The Fluorescence Transient as a Tool to Characterize and Screen Photosynthetic Samples. In: Yunus, M., Ed., Probing Photosynthesis. Mechanisms, Regulation and Adaptation, Taylor and Francis, London, 445-483.

[12] Martinazzo, E.G., Perboni, A.T., Oliveira, P.V., Bianchi, V.J. and Bacarin, M.A. (2015) Atividade fotossintética em plantas de ameixeira submetidas ao déficit hídrico e ao alagamento. Ciência Rural, 43, 35-41. https://doi.org/10.1590/S0103-84782012005000126

[13] Donagema, K.D., Campos, D.V.B., Calderano, S.B., Teixeira, W.G. and Viana, 
J.H.M. (2011) Manual de métodos de análise de solo. 2nd Edition, Embrapa Solos, Rio de Janeiro, RJ.

[14] Ayers, R.S. and Westcot, D.W. (1999) A qualidade da água na agricultura. UFPB, Campina Grande, 218.

[15] Novais, R.F., Neves, J.C.L. and Barros, N.F. (1991) Ensaio em ambiente controlado. In: Oliveira, A.J., Ed., Métodos de pesquisa em fertilidade do solo, 1st Edition, Embrapa SEA, Brasília, 189-253.

[16] Grimes, D.W. and Carter, L.M. (1969) A Linear Rule for Direct Nondestructive Leaf Área Measurements. Agronomy Journal, 3, 477-479. https://doi.org/10.2134/agronj1969.00021962006100030048x

[17] Arnon, D.I. (1949) Copper Enzimes in Isolated Chloroplasts. Polyphenoloxidases in Beta Vulgaris. Plant Physiology, 24, 1-15. https://doi.org/10.1104/pp.24.1.1

[18] Lichtenthaler, H.K. (1987) Chlorophylls and Carotenoids: Pigments of Photosynthetic Biomembranes. In: Packer, L. and Douce, R., Eds. Methods in Enzimology, Academic Press, London, 148, 350-381.

[19] Hendry, G.A.F. and Price, A.H. (1993) Stress Indicators: Chlorophylls and Carotenoids. In: Hendry, G.A.F. and Grime, J.P., Eds., Methods in Comparative Plant Ecology, Chapman \& Hall, London, 148-152. https://doi.org/10.1007/978-94-011-1494-3

[20] Ferreira, D.F. (2014) Sisvar: A Guide for Its Bootstrap Procedures in Multiple Comparisons. Ciência Agrotecnica, 38, 109-112. https://doi.org/10.1590/S1413-70542014000200001

[21] Lima, G.S., Nobre, R.G., Gheyi, H.R., Soares, L.A.A., Pinheiro, F.W.A. and Dias, A.S. (2015) Crescimento, teor de sódio, cloro e relação iônica na mamoneira sob estresse salino e adubação nitrogenada. Comunicata Scientiae, 6, 212-223.

[22] Lima, G.S., Dias, A.S., Soares, L.A.A., Gheyi, H.R., Camara Neto, J.P. and Oliveira, L.D. (2017) Cultivation of CNPA G3 Sesame Irrigated with Saline Water and Fertilized with Nitrate-N and Ammonium-N. Revista Brasileira de Engenharia Agrícola e Ambiental, 21, 14-20. https://doi.org/10.1590/1807-1929/agriambi.v21n1p14-20

[23] Nascimento, S.P., Bastos, E.A., Araujo, E.C.E., Freire Filho, R.R. and Silva, E.M. (2011) Tolerance to Water Deficit of Cowpea Genotypes. Brasileira de Engenharia Agrícola e Ambiental, 15, 853-860. https://doi.org/10.1590/S1415-43662011000800013

[24] Santos, J.B., Gheyi, H.R., Lima, G.S., Xavier, D.A., Cavalcante, L.F. and Centeno, C.R.M. (2016) Morfofisiologia e produção do algodoeiro herbáceo irrigado com águas salinas e adubado com nitrogênio. Comunicata Scientiae, 7, 86-96. https://doi.org/10.14295/cs.v7i1.1158

[25] Dias, A.S., Lima, G.S., Gheyi, H.R., Soares, L.A.A., Souza, L.P. and Bezerra, I.L. (2017) Crescimento do algodoeiro "BRS RUBI" em função da irrigação com águas salinas e adubação nitrogenada. Revista Brasileira de Agricultura Irrigada, 11, 1945-1955. https://doi.org/10.7127/rbai.v11n700660

[26] Lopes, K.P. and Silva, M. (2010) Salinidade na germinação de sementes de algodão colorido. Revista Verde de Agroecologia e Desenvolvimento Sustentável, 5, 274-279.

[27] Munns, R. and Tester, M. (2008) Mechanisms of Salinity Tolerance. Annual Review of Plant Biology, 59, 651-681. https://doi.org/10.1146/annurev.arplant.59.032607.092911 